JOURNAL OF SECURITY AND SUSTAINABILITY ISSUES ISSN 2029-7017 print/ISSN 2029-7025 online 2020 June Volume 9 Number 4 http://doi.org/10.9770/jssi.2020.9.4(20)

Scopus

\title{
THE RELATIONSHIP BETWEEN SUPPLY CHAIN MANAGEMENT AND ORGANIZATION PERFORMANCE: A CASE STUDY
}

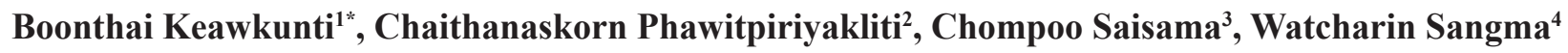 \\ ${ }^{1,2,3,4}$ College of Innovation Management, Suan Sunandha Rajabhat University, Bangkok, Thailand
}

E-mails: ${ }^{1}$ boonthai.ke@ssru.ac.th; ${ }^{2}$ chaithanaskorn.ph@ssru.ac.th; ${ }^{3}$ chompoo.sa@ssru.ac.th; ${ }^{4}$ watcharin.sa@ssru.ac.th

Received 18 November 2019; accepted 12 April 2020; published 30 June 2020

\begin{abstract}
The objective of the study is to examine the mediating impact of competitive advantage on the relationship of supply chain management (SCM) practices and firm performance of the pharmaceutical industry of Thailand. For this purpose, the questionnaires were distributed among the 1400 supply chain manager which yield a $40 \%$ response rate. Based on SEM analysis, it is found that customer relationship (CR), time to market (TM), postponement (POS) have a significant association with the firm performance. While, supplier partnership (SP), information quality (IQ), information sharing (IS) have an insignificant association with the firm performance. On the other hand, it is found POS, CR, IQ, IS, SP have also a significant association with the competitive advantage, whereas, POS is not having a significant association with the competitive advantage. In addition, the mediating effect shows that competitive advantage has a partial mediating among all of the SCM practices and firm performance of the pharmaceutical industry of Thailand. These findings show that competitive advantage is considered to be a significant mediator in the relationship of relationship of SCM practices and firm performance of the pharmaceutical industry of Thailand. The current added a body of literature in the form of empirical findings which could become an area of interest for the future research. The research is also beneficial for the supply chain managers to know about the importance of SCM practices to improve the firm performance through the competitive advantage. The research limitations and future directions are also discussed at the end of the study.
\end{abstract}

Keywords: supply chain management practices; competitive advantage; firm performance; pharmaceutical industry; Thailand

Reference to this paper should be made as follows: Keawkunti, B., Phawitpiriyakliti, C., Saisama, C., Sangma, W. 2020. the relationship between supply chain management and organization performance: a case study, Journal of Security and Sustainability Issues, 9(4), 1349-1361. http://doi.org/10.9770/jssi.2020.9.4(20)

JEL Codes: O32

\section{Introduction}

The need for effective SCM practices is increasing with time due to market globalization, and intensified competition situation exists in the market (Chetthamrongchai \& Jermsittiparsert, 2019; Jermsittiparsert, Namdej, \& Sriyakul, 2019; Somjai \& Jermsittiparsert, 2019). These challenges force the organizations that they escalate their processes in a way that products are available at the right place within the right time and bearing very low cost that leads the organization towards the high profitability. This motive cannot be achieved without effective SCM practices. Thus, the practicing and understanding of SCM now become a vital prerequisite that helps the organization in staying alive in the global competition and enhance organizational performance by generating high profitability (Govindan, Mangla, \& Luthra, 2017; Niño-Amézquita, Legotin, Barbakov, 2017). The effective practices of SCM not only enhance the performance of the individual entity but also enhance the performance of all organization associated with the supply chain (Gupta \& Singh, 2015). Consequently, the SCM refers to the coordination that has strategic nature between the trading partners that achieve the dual goal of SCM: to enhance the individual performance of the entity and to enhance the performance of all the associated companies with supply chain. The SCM now becomes an effective competitive tool that eliminate 
information flows from supply chain and make them able to compete the rivals (Mollel, 2015). Therefore, the attention of business managers, consultants and academicians have increased towards the concept of SCM. In addition, almost all of the organizations have now realized that SCM is an effective tool in building a sustainable competitive advantage for the products in the global market (Mollel, 2015).

The growing importance of SCM with respect to increasing competition and globalization creates an opportunity that this area should be investigated further. Although, several previous studies have been undertaken on the concept of SCM in different perspectives including; management information system, logistics and transportation, organization theory and operations management. Moreover, several theories were also used to explore the SCM concept in different perspectives, namely; competitive strategies, resource-based theory, industrial organization and cost analysis theory (Govindan et al., 2017).. However, the growing reputation of supply chain in the performance of the entities are still gaining the attention of the new researchers on the concept of SCM practices. Moreover, the concept of SCM is based upon two separate paths, namely; transportation and logistics management and supply management. As for as supply management is a concern, it involves the purchasing of goods and supplies them in a very low handling cost by applying the Just in time (JIT) technique. While transportation and logistics management mean the supply of the goods at the right place within the right time that increase the effectiveness of the overall supply chain, these two factors are necessary for the improvement of individual firm performance and performance of the whole supply chain. Based on all the above evidence, this study is also evaluating the firm performance with the help of SCM practices that provide a competitive advantage to the organization (Mollel, 2015).

The complexity and evolutionary nature of SCM are also the reasons for the attraction of researchers toward the practices of SCM. The focus of most of the previous studies had only on the upstream and the downstream side of SCM practices regarding the selection of supplier. The previous studies on the selection of the suppliers are supplier involvement, manufacturing performance, supplier selection, influence of alliances of suppliers, supplier performance and supplier orientation management (Walker \& Jones, 2012). The role of the supplier on buyer and supplier relationship, supplier responsiveness and supplier attitude investigated only on the supplier side. Moreover, some of the studies deals with downward linkage among retailer and manufacturers and few studies consider both downward and upward sides of that relationship with the help supply chain simultaneously. However, several studies are available on the practices of the supply chain, both upwards and downwards streams. Moreover, the linking activities were detracted, and less attention had been paid with reference to SCM practices. Moreover, the previous studies have major focus on the developed economies but has a little attention on the developing economy, especially on the pharmaceutical industry of Thailand. Thus, based on this, the current study examined the role of SCM practices on competitive advantage and organizational performance on the food industry of Thailand.

SCM is one of the major tools that improve the firm performance. The pharmaceutical industry of Thailand is also a growing industry in the country. The involvement of SCM practices in this industry can also increase its performance and give them a competitive edge among other industries in the country (Alvarado \& Kotzab, 2001). The improvement in the performance of the pharmaceutical industry due to the effective supply chain from 2009 to 2015 . The figure 1 shows that the growth of the companies increased from $0 \%$ to $8 \%$ and average growth rate is $2 \%$ due to the supply chain. Moreover, the operating margin of the companies also increased from 0.01 to 0.17 and the average increase in operating margin was 0.1 . In addition, inventory turnover also increased from 5 to 7 units due to the supply chain and the average increase in the turnover was seven units. Furthermore, return on capital and book value were also increased due to the effective supply chain implemented in the companies.

Based on the previous discussions, the aim of the study is to investigate the mediating impact of competitive advantage on the relationship of supply chain management practices and firm performance of pharmaceutical industry of Thailand. The current study was divided into the following sections, introduction, literature review, research methodology, analysis and findings, at last conclusions, limitations and future directions. 


\section{Literature Review and hypothesis development}

This section provides a review of the literature regarding the previous studies on the topic of SCM, competitive advantages and firm performance. This section is divided into subparts; the first part describes the SCM practices, the second part describes competitive advantage, the third part of the section provides the knowledge about organization performance and the rest of the sections show the literature of past studies on the relationships between the variables under study.

\section{SCM Practices}

SCM practices are the activities that are undertaken by the firms to increase the effectiveness of their supply chain. Moreover, (Zare Mehrjerdi 2009) further mentioned that the SCM practices include supplier partnership, continues the flow of the process, cycle time compression, and sharing technology information. Furthermore, (Alvarado and Kotzab 2001) described in their study that the SCM practices include the core competencies, effective internal-organizational system, and understanding the supply chain practices. In addition, SCM practices also include the supply chain integration, JIT capabilities, information sharing and characteristics of the supply chain. (Chen \& Paulraj, 2004). Additionally, agreed goals, risk and reward sharing, sharing information, cooperation and long term relation with partners are the major practices of the supply chain (Chen \& Paulraj, 2004).

The SCM practices has been comprises internal and external practices of the firms that are used to make the supply chain within the organizations more sustainable with respect to three dimensions of the sustainability (Morali \& Searcy, 2013). The firms which has good practiced about the sustainable supply chain are able to enhance their sustainable competences. Various scholars have been done a various research on the SCM practices. Nonetheless, a little attention has been reviewed in the extant literature on SSCM practices and case analysis has been used to discussed about the practices through diversified industries and has been explored the practices in the manufacturing industries (Verma, 2014).

Furthermore, several researcher has been used the qualitative method for analysis to investigate the combination of SCM and the best practices (Esfahbodi, Zhang, \& Watson, 2016; Paulraj, Lado, \& Chen, 2008). In addition, (Paulraj et al. 2008) further categorized the SSCM practices into three perspectives that are "strategic orientation, collaboration, supply chain continuity, risk management and pro- activity". Whereas, Paulraj, Chen, and Blome (2017), further identified SSCM into four dimensions which are process design, product design, and sustainable association with the customer as well as suppliers. Likewise, (Esfahbodi et al. 2016) have also focused on four areas which are, "sustainable design, sustainable distribution, sustainable production and investment in the SSCM practices". Nevertheless, SSCM practices which are discussed in the extant literature streams has the inconsistent findings and also there is little attention on the combined effect of SSCM practices. Therefore, current research has been endeavored to implement the SSCM practices. For this purpose, in the current study has been proposed a five SSCM practices dimensions which are taken about the core practices into the account which are entirely based previous literature stream.

\section{Competitive advantage}

Competitive advantage is the ability of the organization to compete in the market with its competitors. Moreover, the competitive advantage also refers to the extent of the defensible position under the competition over the competitors. In addition, also refers that the capability of the company that allows to differentiate it from the competitors in the market (Mentzer, Min, \& Zacharia, 2000). Furthermore, (Pfeffer, 1994; Pfeffer \& Villeneuve, 1994; Tay, Rahman, Aziz, \& Sidek, 2015; Walker \& Jones, 2012) found in their study that the capabilities that provide the competitive advantage to the company include; premium price, dependable delivery, customer quality, production innovation and competitive pricing. The firm that has above-mentioned capabilities is considered that the firm has a competitive advantage over its rivals in the market. 


\section{Firm performance}

Organizational performance is defined as the ability of the organization that achieves the market- oriented and financial goals of the organization. The short-term goals of the implementation of SCM practices are to enhance the productivity, cycle time and inventory of the firm (Podsakoff \& MacKenzie, 1997). In addition, the long-term goals of the implementation of practices of SCM are to enhance the profits, market share and investment of the company and all the other entities of supply chain. "Financial metrics" are considered as a vital tool of comparing and measuring organizational behavior over time (Dess \& Robinson Jr, 1984). The effective supply chain leads to increase the organizational performance by providing a competitive advantage to the firm. Most of the previous studies used the financial as well as market criteria to measure the organizational performance variable of the study.

\section{SCM practices and firm performance}

Several studies examine the capabilities of SCM practices with reference to organizational performance, and this section of the study provides a review of previous literature on the relationship between SCM practices and organizational performance. A study by (M. Lo 2013) conducted on the supply chain of several industries in Hong Kong and Taiwan. They found that the organizational performance in term of customer satisfaction, strategies of supplier participation and reduction in the cost of products are influenced by the effective supply chain practices. They also revealed that effective SCM practices are a necessary element for the improvement of organizational performance of Hong Kong and Taiwan. Moreover, (Wook Kim 2006) conducted the study on firms and explained that SCM practices are the vital tool for the logistics performance. In addition, effective SCM practices are not only influenced the market performance of the firm but also have influenced the financial performance of the firm positivity. Furthermore, (Germain, Claycomb, and Dröge 2018) conducted the study on the variability of SCM process to check the level of inconsistency regarding the impact of SCM practices and revealed that variability in the process of SCM could improve the financial performance of the firm. Based on all studies mentioned above, this study develops the following hypothesis:

H1: Customer Relationship has a significant association with the firm performance of pharmaceutical industry of Thailand.

H2: Supplier's Partnership has a significant association with the firm performance of pharmaceutical industry of Thailand.

H3: Information quality has a significant association with the firm performance of pharmaceutical industry of Thailand.

H4: Information system has a significant association with the firm performance of pharmaceutical industry of Thailand.

H5: Postponement has a significant association with the firm performance of pharmaceutical industry of Thailand.

H6: Time to market has a significant association with the firm performance of pharmaceutical industry of Thailand.

\section{SCM and competitive advantage}

The SCM practices enable that create a competitive advantage for the firm in the market. In addition, (Liao, $\mathrm{Hu}, \&$ Ding, 2017) conducted the study on sustainable practices of the supply chain by using secondary data and indicated that sustainable practices of SCM could create a competitive advantage for the firm. Moreover, (Wu, Tseng, Chiu, and Lim 2017) mentioned that the topic of competitive advantage with practices of SCM was ignored by previous studies. They also indicated that competitive advantage could be achieved through the effective practices of the supply chain. Similarly, a study conducted by (Ploenhad, Laoprawatchai, Thongrawd, and Jermsittiparsert 2019) on the industry and indicated that positive practices SCM could be able to bring 
the competitive advantage for the SCM implemented firmly. Based on all studies mentioned above, this study develops the following hypothesis:

H7: Customer Relationship has a significant association with the competitive advantage of pharmaceutical industry of Thailand.

H8: Supplier's Partnership has a significant association with the competitive advantage of pharmaceutical industry of Thailand.

H9: Information quality has a significant association with the competitive advantage of pharmaceutical industry of Thailand.

H10: Information system has a significant association with the competitive advantage of pharmaceutical industry of Thailand.

H11: Postponement has a significant association with the competitive advantage of pharmaceutical industry of Thailand.

H12: Time to market has a significant association with the competitive advantage of pharmaceutical industry of Thailand.

\section{Competitive Advantage and Organizational Performance}

Several studies examine the capabilities of competitive advantage with reference to the organizational performance and provides the review of previous literature on the relationship of "competitive advantage" and organizational performance. Moreover, conducted the study on food firms and revealed that the competitive advantage creates the extra demand for the products that enhance the performance of the organization (Rahman \& Hamid, 2019). Similarly, a study conducted by (Akhir, Ahmad, Ahmad, and Hashim 2018); (Kasasbeh, Harada, \& Noor, 2017) on the manufacturing companies of Australia. They indicted in their study that growing competition in the market is required to take the competitive advantage on the rivals exist in the market. This competitive advantage can lead the organization to improved financial performance. In addition, (Kumar and Pansari 2016) and (Ashrafi and Mueller 2015) analyzed in their study that any type of competitive advantage can improve the process of the business that can lead the business towards high performance. Based on all studies mentioned above, this study develops the following hypothesis:

H14: Competitive advantage has a significant association with the firm performance.

\section{Mediating Role of Competitive Advantage on the Relationship of SCM Practices and Organizational Performance}

The effective practices of SCM can create a competitive advantage for the firm, and this advantage improved the performance of the firm. A study by (Uca, Çemberci, Civelek, and Y1lmaz 2017) and (Cao and Zhang 2011) found that the supply chain improves the collaboration between the firm and its suppliers, that create collaboration advantage for the firm that helps the organization to improve its performance. Similarly, (EscorciaCaballero, Moreno-Luzon, \& Chams-Anturi, 2019) investigated a study and indicated in his study that SCM practices increase the internal and external integration, and this competitive advantage can increase the firm performance. Moreover, the practices of supply chain enhance the relationship with suppliers, vendors and customer. This competitive advantage also increases the performance of the firm (Ploenhad et al., 2019). Based on all the studies mentioned above, this study develops the following hypothesis:

H14: Competitive advantage has mediated the relationship of Customer Relationship and firm performance of the pharmaceutical industry of Thailand. 
H15: Competitive advantage has mediated the relationship of Supplier's Partnership and firm performance of the pharmaceutical industry of Thailand.

H14: Competitive advantage has mediated the relationship of information quality and firm performance of the pharmaceutical industry of Thailand.

H14: Competitive advantage has mediated the relationship of information sharing and firm performance of the pharmaceutical industry of Thailand.

H14: Competitive advantage has mediated the relationship of postponement and firm performance of the pharmaceutical industry of Thailand.

H14: Competitive advantage has mediated the relationship of Time to market and firm performance of the pharmaceutical industry of Thailand.

Based on previous literature review and hypothesis development section, the research framework of the study is formulated in the Figure 1

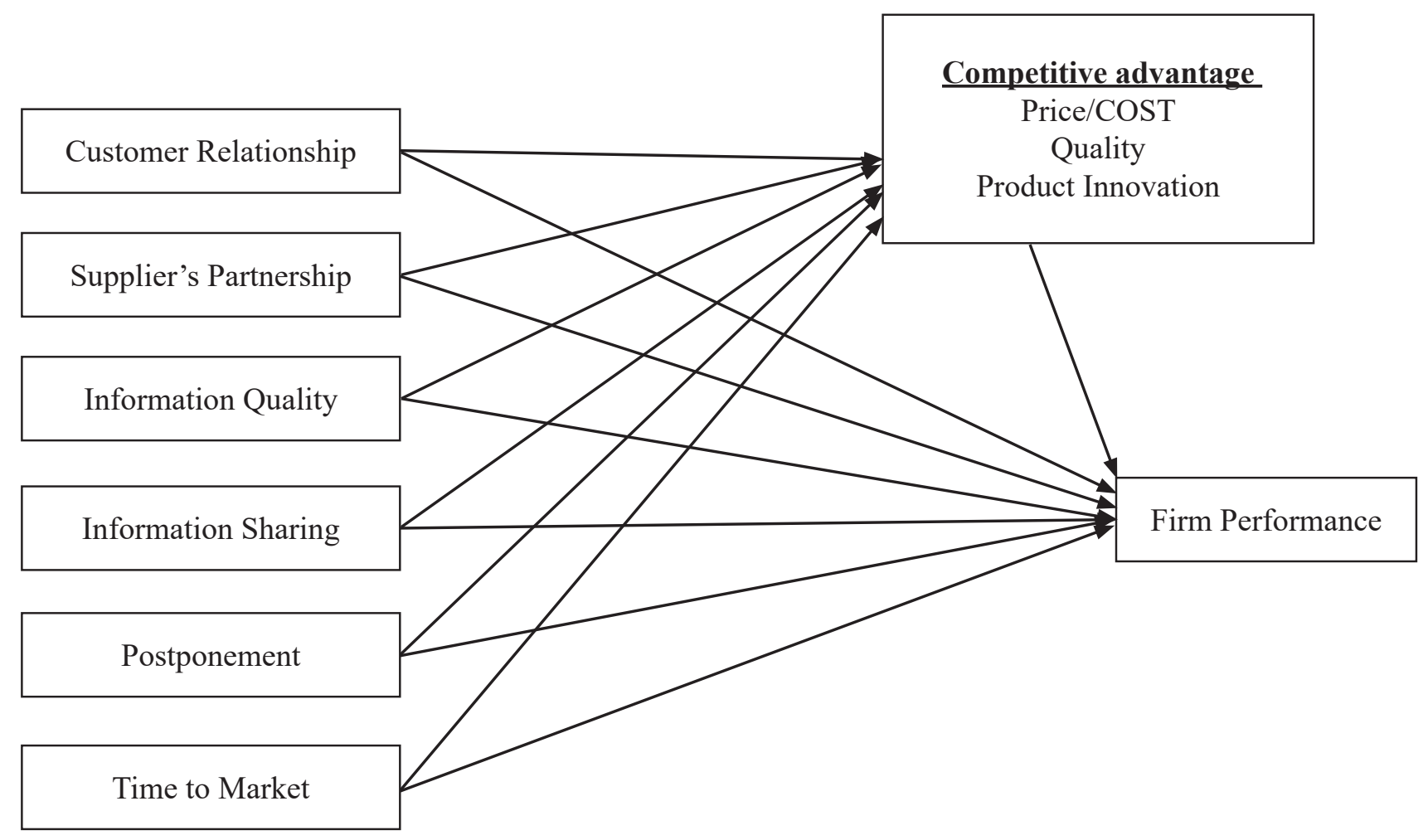

\section{Research Methodology}

Primary data were collected through a questionnaire for analysis. The list of the respondent was collected from the "Department of pharmaceutical Industrial Work Thailand", respondents were the managers of the supply chain working in the pharmaceutical industry of Thailand. However, the companies who have not the separate department of SCM, they data were collected form the top-level executives or production mangers who know the practices of SCM. At the first stage, 1,400 respondents were selected and send them the questionnaire for data requirement. Only 586 questionnaires were returned from the respondents out of them 26 responses were not meet the satisfactory criteria and excluded from the analysis. Thus, only 560 valid responses were remained for analysis that was approximately $40 \%$ response rate. Furthermore, many of the questions in the survey were changed according to the environment and nature of the study and its scope. Five points Likert scale was used to answer the questions (from 1 for strongly disagree to 5 for strongly agree) (Ahmad, Bin Mohammad, \& Nordin, 2019). 


\section{Research Instrument}

SCM practices have five dimensions, the first dimension is strategic supplier partnership (SSP) that have six items, customer relationship (CR) is the second dimension that has five items, information sharing (IS) is the third dimension that has six items, information quality (IQ) is the fourth dimension that has five items and Postponement (POS) is the last dimension that has three items. In addition, competitive advantage also has five dimensions, the first dimension is price/cost $(\mathrm{P} / \mathrm{C})$ that have two items, quality $(\mathrm{Q})$ is the second dimension that has four items, delivery dependability (DD) is the third dimension that has three items, product innovation (PI) is the fourth dimension that has three items and time to market (TM) is the last dimension that has four items. Finally, organizational performance is the one- dimensional variable that has seven items.

\section{Data Collection Procedure}

An email sent to the supply chain managers and other top-level managers where the separate SCM department did not exist, to obtain the consent regarding data collection. Total 1,400 questionnaires were sent to the managers after getting consent from them, but only 586 responses were returned. Moreover, 26 responses out of 586 were not up to the standard and eliminated from the analysis. Finally, 560 valid responses were selected for analysis purpose.

\section{Analysis of the study}

The analysis of the study is consisting of two section one is measurement model and other one is structural model.

\section{Measurement Model}

This study used the PLS-SEM to investigate the relationships among under study variables. The validity of the items and constructs must be check before to test the relationships between variables. There are four criteria to check the convergent validity of the items (Hair, Hollingsworth, Randolph, \& Chong, 2017); the first criteria is outer loadings that should be greater than 0.50 . According to the results of this study, the outer loadings of almost all items are greater than 0.05 that means no problem with convergent validity. The second criteria are Cronbach's Alpha that should be greater than 0.07, and the results show that the value of Cronbach's Alpha is more than the limit that means no issue with convergent validity. The third criteria are composite reliability (CR) that should be greater than 0.07, and the results show that the value of CR is more than the limit, that means no issue with convergent validity. The last criteria are Average Variance Extracted (AVE) that should be greater than 0.05 , and the results show that the value of AVE is more than the limit that means no issue with convergent validity (Hair et al., 2017; Henseler, Ringle, \& Sarstedt, 2015). In addition, the validity of the model could also be assessed by the discriminant validity of the model. The discriminant validity of model could be assessed by following three areas, for instance, fornell lacker, HTMT, and cross loading. In the fornell lacker the diagonal value should be greater than from other value and for HTMT the construct association should be less than from 0.90 (Henseler et al., 2015) (See table 1, table 2, table 3, figure 2).

Table 1. Measurement Model Results

\begin{tabular}{|c|c|c|c|c|c|c|}
\hline 1st Order Constructs & 2nd Order Constructs & Items & Loadings & Alpha & $\mathbf{C R}$ & AVE \\
\hline \multirow[t]{5}{*}{ Firm Performance } & & FP1 & 0.814 & 0.907 & 0.931 & 0.729 \\
\hline & & FP2 & 0.888 & & & \\
\hline & & FP3 & 0.853 & & & \\
\hline & & FP4 & 0.895 & & & \\
\hline & & FP5 & 0.816 & & & \\
\hline \multirow[t]{4}{*}{ Customer Relationship } & & CR1 & 0.826 & 0.905 & 0.934 & 0.78 \\
\hline & & CR2 & 0.909 & & & \\
\hline & & CR3 & 0.92 & & & \\
\hline & & CR5 & 0.875 & & & \\
\hline
\end{tabular}


Supplier Partnership

Information Quality

Information Sharing

Postponement

Time to Market

Price / Cost

Product Innovation
Quality
SP1

SP2

SP3

SP4

SP5

IQ1

IQ2

IQ4

IQ5

IS1

IS2

IS4

IS5

POS1

POS2

POS3

TM1

TM2

TM3

TM4

PC1

PC2

PI2

PI3

0.783

0.849

0.756

0.734

0.723

0.856

0.916

0.885

0.883

0.82

0.864

0.82

0.884

0.882

0.862

0.875

0.945

0.92

0.915

0.91

0.958

0.962

0.823

0.849

Q1

0.872

0.93

Q2

Q3

Q4

IM

Competitive Advantage

$\begin{array}{ccccc}\text { IM } & 0.247 & 0.892 & 0.852 & 0.675 \\ \text { PC } & 0.733 & & & \\ \text { PI } & 0.842 & & & \\ \text { Q } & 0.851 & & & \end{array}$

Note: CR-Customer Relationship, TM- Time to Market, IQ-information quality, IS-information sharing, FP-firm performance, POS-Postponement, TM-Time to Market, PC-Price / Cost, PI-Product Innovation, Q-Quality, CA-competitive advantage, SP-supplier partnership.

Table 2. Discernment Validity: Fornell Lacker

\begin{tabular}{|c|c|c|c|c|c|c|c|c|c|c|}
\hline & CR & TM & IQ & IS & FP & PC & PI & POS & Q & SP \\
\hline CR & 0.808 & & & & & & & & & \\
\hline TM & 0.071 & 0.760 & & & & & & & & \\
\hline IQ & 0.562 & 0.119 & 0.90 & & & & & & & \\
\hline IS & 0.796 & 0.056 & 0.589 & 0.95 & & & & & & \\
\hline FP & 0.511 & 0.164 & 0.533 & 0.499 & 0.86 & & & & & \\
\hline $\mathrm{PC}$ & 0.275 & 0.032 & 0.41 & 0.416 & 0.557 & 0.845 & & & & \\
\hline PI & 0.476 & 0.104 & 0.715 & 0.578 & 1.026 & 1.079 & 0.865 & & & \\
\hline POS & 0.693 & 0.087 & 0.698 & 0.704 & 0.579 & 0.49 & 0.748 & 0.90 & & \\
\hline Q & 0.511 & 0.177 & 0.46 & 0.495 & 0.836 & 0.482 & 0.846 & 0.607 & 0.780 & \\
\hline SP & 0.334 & 0.076 & 0.579 & 0.469 & 0.615 & 0.751 & 0.451 & 0.483 & 0.513 & 0,790 \\
\hline
\end{tabular}

Note: CR-Customer Relationship, TM- Time to Market, IQ-information quality, IS-information sharing, FP-firm performance, POS-Postponement, TM-Time to Market, PC-Price / Cost, PI-Product Innovation, Q-Quality, SP-supplier partnership. 
Table 3. Discernment Validity (HTMT)

\begin{tabular}{ccccccccccc}
\hline & CR & TM & IQ & IS & OP & PC & PI & POS & Q & SP \\
\hline CR & & & & & & & & & & \\
TM & 0.071 & & & & & & & & \\
IQ & 0.562 & 0.119 & & & & & & & \\
IS & 0.796 & 0.056 & 0.589 & & & & & & \\
OP & 0.511 & 0.164 & 0.533 & 0.499 & & & & & \\
PC & 0.275 & 0.032 & 0.41 & 0.416 & 0.557 & & & & \\
PI & 0.476 & 0.104 & 0.715 & 0.578 & 1.026 & 1.079 & & & \\
POS & 0.693 & 0.087 & 0.698 & 0.704 & 0.579 & 0.49 & 0.748 & & \\
Q & 0.511 & 0.177 & 0.46 & 0.495 & 0.836 & 0.482 & 0.806 & 0.607 & \\
SP & 0.334 & 0.076 & 0.579 & 0.469 & 0.615 & 0.751 & 0.487 & 0.483 & 0.513 \\
\hline
\end{tabular}

Note: CR-Customer Relationship, TM- Time to Market, IQ-information quality, IS-information sharing, FP-firm performance, POS-Postponement, TM-Time to Market, PC-Price / Cost, PI- Product Innovation, Q-Quality, SP-supplier partnership.

\section{Structural Model of the Study}

The SEM analysis of the study shows that customer relationship (CR), Postponement (POS), time to market (TM) have positive and significant relationship with the firm performance, while supplier partnership (SP), information quality (IQ), information system (IS) have insignificant association with the FP. On the other hand, the key findings show that CR, TM, SP, IQ, and IS have positive and significant association with the competitive advantage. However, POS has a negative and insignificant association with the CA. Moreover, the indirect effect of the study show that CA is partially mediates among all the supply chain management practices (POS, IQ, TM, IS, CR, SP) and FP. These findings indicate that CA is considered to be a significant mediating variable which could help to enhance the FP of pharmaceutical industry of Thailand. This shows that supply chain management practices (SCMP) through the CA could increase the FP of the pharmaceutical industry of Thailand. All of the results of the findings are depicted in following Table 4.

Table 4. Direct and Indirect Effect of the Model

\begin{tabular}{cccccc}
\hline & Beta & SD & Statistics & P Values & Results \\
\hline CR-> FP & 0.202 & 0.075 & 2.698 & 0.007 & supported \\
SP> FP & 0.043 & 0.079 & 0.546 & 0.586 & Not supported \\
IQ ->FP & -0.172 & 0.177 & 0.969 & 0.333 & Not supported \\
IS->FP & 0.054 & 0.112 & 0.483 & 0.629 & Not supported \\
POS->FP & 0.259 & 0.067 & 3.878 & 0.000 & supported \\
TM->FP & 0.242 & 0.08 & 3.022 & 0.003 & supported \\
CR-> CA & -0.153 & 0.07 & 2.19 & 0.029 & supported \\
SP> CA & 0.281 & 0.056 & 5.025 & 0.00 & supported \\
IQ ->CA & 0.203 & 0.064 & 3.172 & 0.002 & supported \\
IS->CA & -0.137 & 0.067 & 2.043 & 0.042 & supported \\
POS->CA & -0.055 & 0.082 & 0.672 & 0.502 & Not supported \\
TM->CA & 0.281 & 0.084 & 3.325 & 0.001 & supported \\
CR-> CA-> FP & 0.249 & 0.071 & 3.518 & 0.000 & supported \\
SP>CA-> FP & 0.244 & 0.086 & 2.835 & 0.005 & supported \\
IQ ->CA-> FP & -0.178 & 0.075 & 2.375 & 0.018 & Supported \\
IS->CA-> FP & 0.281 & 0.055 & 5.113 & 0.000 & supported \\
POS->CA-> FP & 0.218 & 0.072 & 3.022 & 0.003 & supported \\
TM->CA-> FP & -0.15 & 0.065 & 2.304 & 0.022 & supported \\
\hline
\end{tabular}

Note: CR-Customer Relationship, TM- Time to Market, IQ-information quality, IS-information sharing, FP-firm performance, POS- Postponement, TM-Time to Market, CA-competitive advantage, $p<0.05$ 


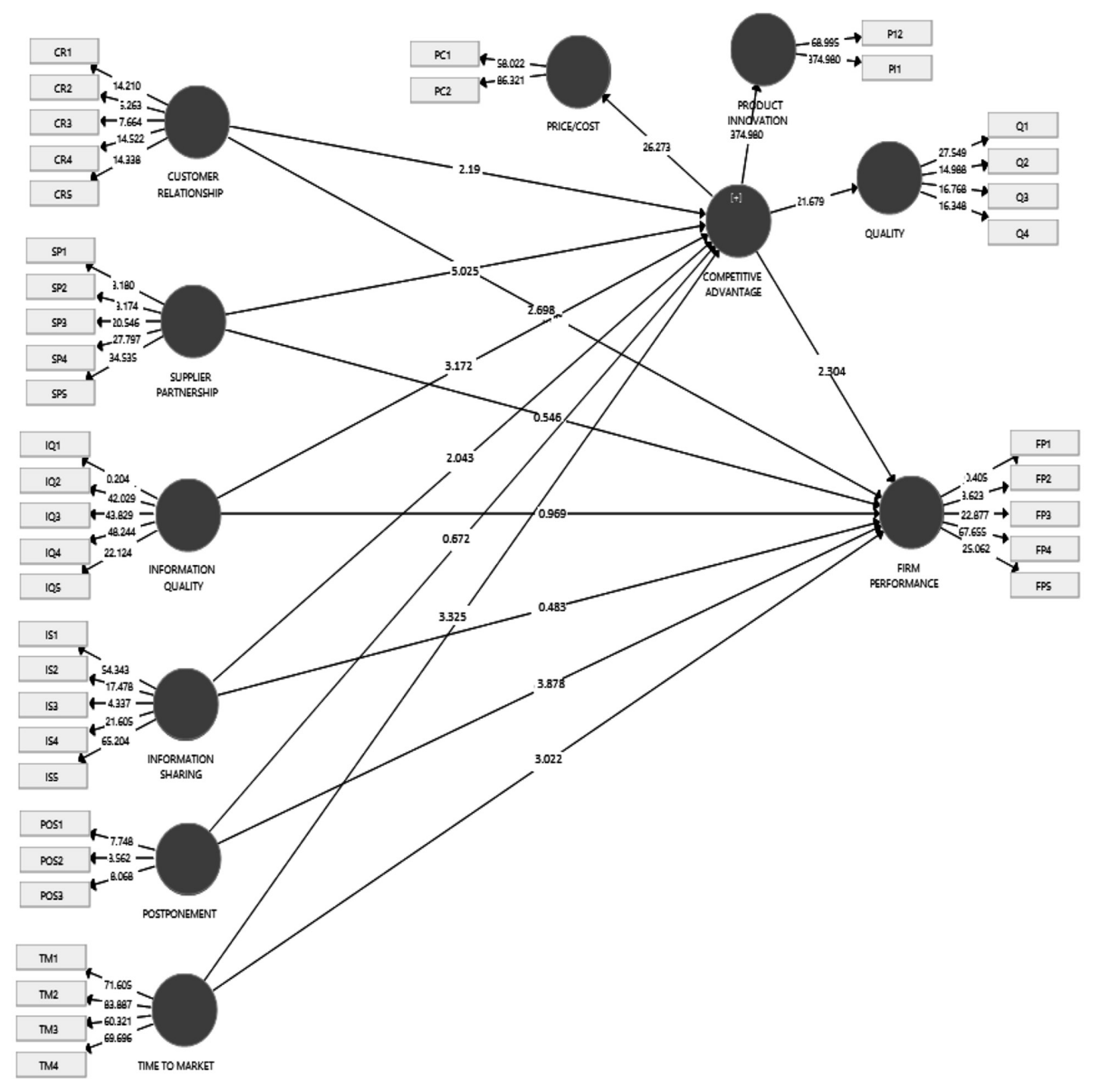

Figure 2. Structural model of the study

\section{Conclusion and Discussion}

This last section of the study provides a discussion regarding the results that are mentioned above in the study. Moreover, it also provides the comparison of current study results with the results of past studies, and finally, it presents the conclusion, the suggestion to future researchers and limitations of the study. Increase the performance of an organization is the prime goal of every personal in the world. The focus of the organization is only on the enhance the performance by applying different strategies and tools in the business processes. Supply chain practices the major tool that boosts up the process of the business in a way that it enhances the capacity of the firm to perform better and generate more profit for the business. This study also investigated the SCM practices impact on the performance of the business with the mediating role of competitive advantage. The results revealed that

longitudinal in nature. Thus, this study is highly recommended to the future research that the incorporate the above-mentioned gaps and explore this area in a different perspective who found that supply chain gains the competitive advantage that achieves the high-performance goal of the firm. Finally, this study concluded that effective practices of SCM could increase organization performance and also brings a competitive advantage for the firm. In addition, competitive advantage has a positive association with organizational performance. Moreover, it also concluded that SCM practices bring the competitive advantage that leads the companies 
towards high financial and market performance. Thus, the competitive advantage mediates the relationship between the practices of SCM and organizational performance.

This study has several limitations that are the gaps for future researchers. This study uses only one factor to measure the performance of the firm. There are several factors are also existing that influenced the performance of the firm. The scope of the study is very limited, only one industry is used for the analysis and ignored the other important industry. Moreover, this study focusses only one country and ignored the cross-country analysis. In addition, the study was consisting of cross-sectional research design in which collect a data at one time, therefore a future research could be done which is longitudinal in nature.

\section{Reference}

Ahmad, R., Bin Mohammad, H., \& Nordin, S. B. (2019). Moderating effect of board characteristics in the relationship of structural capital and business performance: An evidence on Pakistan textile sector. Journal of Studies in Social Sciences and Humanities, 5(3), 89-99.

Akhir, R. M., Ahmad, S. N. B., Ahmad, H., \& Hashim, N. A. (2018). Staying or Leaving? The Influence of Employees' Engagement towards Turnover Decision Among Employees of A Semi-Government Organization in Malaysia. Humanities, 3(1), 55-62. https://doi. org/10.20448/801.31.55.62

Alvarado, U. Y., \& Kotzab, H. (2001). Supply chain management: the integration of logistics in marketing. Industrial Marketing Management, 30(2), 183-198. https://doi.org/10.1016/S0019-8501(00)00142-5

Ashrafi, R., \& Mueller, J. (2015). Delineating IT resources and capabilities to obtain competitive advantage and improve firm performance. Information Systems Management, 32(1), 15-38. https://doi.org/10.1080/10580530.2015.983016

Cao, M., \& Zhang, Q. (2011). Supply chain collaboration: Impact on collaborative advantage and firm performance. Journal of Operations management, 29(3), 163-180. https://doi.org/10.1016/j.jom.2010.12.008

Chen, I. J., \& Paulraj, A. (2004). Towards a theory of supply chain management: the constructs and measurements. Journal of Operations management, 22(2), 119-150. https://doi.org/10.1016/j.jom.2003.12.007

Chetthamrongchai, P. \& Jermsittiparsert, K. (2019). The Mediating Role of Supply Chain Management Practices in the Relationship between Manufacturing Flexibility and Manufacturing Performance. Humanities and Social Sciences Reviews, 7(3), 736-743. https:// doi.org/10.18510/hssr.2019.73104.

Dess, G. G., \& Robinson Jr, R. B. (1984). Measuring organizational performance in the absence of objective measures: the case of the privately-held firm and conglomerate business unit. Strategic management journal, 5(3), 265-273. https://doi.org/10.1002/ smj.4250050306

Escorcia-Caballero, J. P., Moreno-Luzon, M. D., \& Chams-Anturi, O. (2019). Supply Chain Integration Capability: An Organizational Routine Perspective. Int. J Sup. Chain. Mgt Vol, 8(5), 39.

Esfahbodi, A., Zhang, Y., \& Watson, G. (2016). Sustainable supply chain management in emerging economies: Trade-offs between environmental and cost performance. International Journal of Production Economics, 181, 350-366. https://doi.org/10.1016/j. ijpe. 2016.02 .013

Germain, R., Claycomb, C., \& Dröge, C. (2018). Supply chain variability, organizational structure, and performance: the moderating effect of demand unpredictability. Journal of Operations management, 26(5), 557-570. https://doi.org/10.1016/j.jom.2007.10.002

Govindan, K., Mangla, S. K., \& Luthra, S. (2017). Prioritising indicators in improving supply chain performance using fuzzy AHP: insights from the case example of four Indian manufacturing companies. Production Planning \& Control, 28(6-8), 552-573. https://doi. $\operatorname{org} / 10.1080 / 09537287.2017 .1309716$

Gupta, T. K., \& Singh, V. (2015). A systematic approach to evaluate supply chain management environment index using graph theoretic approach. International Journal of Logistics Systems and Management, 21(1), 1-45. https://dx.doi.org/10.1504/IJLSM.2015.069077

Hair, Hollingsworth, C. L., Randolph, A. B., \& Chong, A. Y. L. (2017). An updated and expanded assessment of PLS-SEM in information systems research. Industrial Management \& Data Systems, 117(3), 442-458. https://dx.doi.org/10.1108/IMDS-04-2016-0130

Henseler, J., Ringle, C. M., \& Sarstedt, M. (2015). A new criterion for assessing discriminant validity in variance-based structural equation modeling. Journal of the academy of marketing science, 43(1), 115-135. https://doi.org/10.1007/s11747-014-0403-8 
Jermsittiparsert, K., Namdej, P., \& Sriyakul, T. (2019). Impact of Quality Management Techniques and System Effectiveness on the Green Supply Chain Management Practices. International Journal of Supply Chain Management, 8(3), 120-130.

Kasasbeh, E. A., Harada, Y., \& Noor, I. M. (2017). Factors Influencing Competitive Advantage in Banking Sector: A Systematic Literature Review. Research Journal of Business Management, 11(2), 67-73. https://doi.org/10.3923/rjbm.2017.67.73

Kumar, V., \& Pansari, A. (2016). Competitive advantage through engagement. Journal of marketing research, 53(4), 497-514. https:// doi.org/10.1509\%2Fjmr.15.0044

Liao, S.-H., Hu, D.-C., \& Ding, L.-W. (2017). Assessing the influence of supply chain collaboration value innovation, supply chain capability and competitive advantage in Taiwan's networking communication industry. International Journal of Production Economics, 191, 143-153. https://doi.org/10.1016/j.ijpe.2017.06.001

M. Lo, S. (2013). Effects of supply chain position on the motivation and practices of firms going green. International Journal of Operations \& Production Management, 34(1), 93-114. https://doi.org/10.1108/IJOPM-04-2012-0133

Mentzer, J. T., Min, S., \& Zacharia, Z. G. (2000). The nature of interfirm partnering in supply chain management. Journal of retailing, 76(4), 549-568. https://doi.org/10.1016/S0022-4359(00)00040-3

MOLLEL, A. A. (2015). Impact of supply chain management practices on Organizational performance in food processing Firms of Dar es salaam, Tanzania. Mzumbe University,

Morali, O., \& Searcy, C. (2013). A review of sustainable supply chain management practices in Canada. Journal of Business Ethics, 117(3), 635-658. https://doi.org/10.1007/s10551-012-1539-4

Niño-Amézquita, J., Legotin, F., Barbakov, O. (2017). Economic success and sustainability in pharmaceutical sector: a case of Indian SMEs. Entrepreneurship and Sustainability Issues, 5(1), 157-168._http://doi.org/10.9770/jesi.2017.5.1(13)

Paulraj, A., Chen, I. J., \& Blome, C. (2017). Motives and performance outcomes of sustainable supply chain management practices: A multi-theoretical perspective. Journal of Business Ethics, 145(2), 239-258. https://doi.org/10.1007/s10551-015-2857-0

Paulraj, A., Lado, A. A., \& Chen, I. J. (2008). Inter-organizational communication as a relational competency: Antecedents and performance outcomes in collaborative buyer-supplier relationships. Journal of Operations management, 26(1), 45-64. https://doi. org/10.1016/j.jom.2007.04.001

Pfeffer, J. (1994). Competitive advantage through people. California management review, 36(2), 9.

Pfeffer, J., \& Villeneuve, F. (1994). Competitive advantage through people: Unleashing the power of the work force (Vol. 61): Harvard Business School Press Boston, MA.

Ploenhad, J., Laoprawatchai, P., Thongrawd, C., \& Jermsittiparsert, K. (2019). Mediating Role of Competitive Advantage on the Relationship of Supply Chain Management and Organizational Performance on the Food Industry of Thailand. International Journal of Supply Chain Management, 8(4), 216-226.

Podsakoff, P. M., \& MacKenzie, S. B. (1997). Impact of organizational citizenship behavior on organizational performance: A review and suggestion for future research. Human performance, 10(2), 133-151. https://doi.org/10.1207/s15327043hup1002_5

Rahman, A. R. A., \& Hamid, N. R. A. (2019). Achieving Logistics Performance in Military Environmental Dynamism: The Role of Organizational Capabilities. Int. J Sup. Chain. Mgt Vol, 8(2), 1004.

Somjai, S. \& Jermsittiparsert, K. (2019). Role of Pressures and Green Supply Chain Management Practices in Enhancing the Operational Efficiency of Firms: Evidence from Thailand. International Journal of Supply Chain Management, 8(4), 437-445.

Tay, M. Y., Rahman, A. A., Aziz, Y. A., \& Sidek, S. (2015). A review on drivers and barriers towards sustainable supply chain practices. International Journal of Social Science and Humanity, 5(10), 892. https://doi.org/10.7763/IJSSH.2015.V5.575

Uca, N., Çemberci, M., Civelek, M. E., \& Y1lmaz, H. (2017). The effect of trust in supply chain on the firm performance through supply chain collaboration and collaborative advantage.

Verma, A. S. (2014). Sustainable supply chain management practices: Selective case studies from Indian hospitality industry. International Management Review, 10(2), 13-23.

Walker, H., \& Jones, N. (2012). Sustainable supply chain management across the UK private sector. Supply Chain Management: An International Journal, 17(1), 15-28. https://doi.org/10.1108/13598541211212177 
Wook Kim, S. (2006). Effects of supply chain management practices, integration and competition capability on performance. Supply Chain Management: An International Journal, 11(3), 241-248. https://doi.org/10.1108/13598540610662149

Wu, K.-J., Tseng, M.-L., Chiu, A. S., \& Lim, M. K. (2017). Achieving competitive advantage through supply chain agility under uncertainty: A novel multi-criteria decision-making structure. International Journal of Production Economics, 190, 96-107. https://doi. org/10.1016/j.ijpe.2016.08.027

Zare Mehrjerdi, Y. (2009). Excellent supply chain management. Assembly Automation, 29(1), 52-60. https://doi.org/10.1108/ 01445150910929866

Boonthai KEAWKUNTI is a Lecturer of Innovative Management Program, College of Innovation Management, Suan Sunandha Rajabhat University, Thailand. His research areas are Business Administration, Innovation Management, and Leadership.

Chaithanaskorn PHAWITPIRIYAKLITI is an Assistant Professor of Professional Football Management Program, College of Innovation Management, Suan Sunandha Rajabhat University, Thailand. His research areas are Innovation Management, Digital Marketing, and Sport Management.

Chompoo SAISAMA is a Lecturer of e-Sport Management Program, College of Innovation Management, Suan Sunandha Rajabhat University, Thailand. Her research areas are Innovation Management, e-Sport Management and Marketing.

Watcharin SANGMA is a Lecturer of Innovative Management Program, College of Innovation Management, Suan Sunandha Rajabhat University, Thailand. His research areas are Innovation Management, Industrial Management, and Materials Handling Technology.

ORCID ID: orcid.org/0000-0002-9667-3730

Register for an ORCID ID:

https://orcid.org/register

This work is licensed under the Creative Commons Attribution International License (CC BY). http://creativecommons.org/licenses/by/4.0/ 